\title{
A systematic review of clinical outcomes on the WHO Category II retreatment regimen for tuberculosis
}

\author{
D. B. Cohen, ${ }^{* t \neq}$ J. Meghji, ${ }^{\star \dagger}$ S. B. Squire* \\ *Liverpool School of Tropical Medicine, Liverpool, UK; 'Malawi-Liverpool-Wellcome Clinical Research Programme, \\ Blantyre, Malawi; ${ }^{\ddagger}$ University of Sheffield, Sheffield, UK
}

S U M M AR Y

OвJECTIVE: To assess the clinical outcomes of patients prescribed the World Health Organization (WHO) Category II retreatment regimen for tuberculosis (TB). DESIGN: A systematic review of the literature was performed by searching Medscape, Embase and Scopus databases for cohort studies and clinical trials reporting outcomes in adult patients on the Category II retreatment regimen.

RESULTS: The proportion of patients successfully completing the retreatment regimen varied from $27 \%$ to $92 \%$ in the 39 studies included in this review. In only $2 /$ $39(5 \%)$ studies was the treatment success rate $>85 \%$. There are very few data concerning outcomes in patients categorised as 'other', and outcomes in this subgroup are variable. Of the five studies reporting disaggregated outcomes in human immunodeficiency virus (HIV) positive people, four demonstrated worse outcomes than in HIV-negative people on the retreatment regimen. Only four studies reported disaggregated outcomes in patients with isoniazid (INH) resistance, and treatment success rates varied from $11 \%$ to $78 \%$.

CONCLUSION: Clinical outcomes on the Category II retreatment regimen are poor across various populations. Improvements in management should consider the holistic treatment of comorbidity and comprehensive approaches to drug resistance in patients with recurrent $\mathrm{TB}$, including a standardised approach for the management of INH resistance in patients who develop recurrent $\mathrm{TB}$ in settings without reliable access to comprehensive drug susceptibility testing.

KEY WORDS: relapse; recurrent; streptomycin; cure; isoniazid
OF THE 6.6 MILLION PEOPLE worldwide reported to have tuberculosis (TB) in 2016, approximately 300000 had previously received treatment. ${ }^{1}$ Until recently, in settings with low or medium prevalence of multidrug-resistant TB (MDR-TB, defined as TB resistant to at least isoniazid [INH, $\mathrm{H}]$ and rifampicin [RMP, R]) and no routine access to drug susceptibility testing (DST), the World Health Organization (WHO) recommended that previously treated patients with $\mathrm{TB}$ be prescribed an empirical regimen comprising 2 months of RMP, INH, pyrazinamide (Z), ethambutol (E) and streptomycin (SM, S), followed by 1 month of RHZE and 5 months of RHE. ${ }^{2}$ This 'Category II' regimen was devised based on expert opinion; however, there have been no clinical trial data on which to assess its efficacy. WHO guidelines published in 2017 recommended that the Category II regimen should no longer be prescribed and that DST be conducted to inform the choice of treatment regimen. ${ }^{3}$ However, given the lack of data on which to base decisions regarding retreatment, this recommendation is presented only as a good practice statement.

In 1991, the World Health Assembly set a target to cure $85 \%$ of patients who receive treatment for sputum smear-positive TB. ${ }^{4}$ In recent years, giant steps have been taken to meet these targets, with $83 \%$ of new cases now successfully cured. ${ }^{1}$ However, rates of successful treatment are consistently lower in patients prescribed the retreatment regimen. A meta-analysis of studies evaluating outcomes in patients who were retreated for TB identified only six cohort studies reporting outcomes for the Category II regimen. 5 These studies demonstrated treatment failure rates of between $0 \%$ and $27 \%$ in patients infected with a fully susceptible strain of TB; however, in patients with INH monoresistance (INHR) and either mixed or unknown resistance patterns, failure rates were even higher, at respectively $18-44 \%$ and $9-45 \%$. This meta-analysis only included patients with microbiologically confirmed TB, and therefore excluded a large number of patients who had sputum smear-negative or extra-pulmonary TB (EPTB), and in whom outcomes are likely to be even worse. $^{6}$

Patients receiving Category II retreatment are classified into four categories: sputum smear-positive

Correspondence to: Danielle B Cohen, Liverpool School of Tropical Medicine, Pembroke Place, Liverpool L3 5QA, UK. email: danbcohen@yahoo.com

Article submitted 11 December 2017. Final version accepted 21 April 2018.

[Versions in French and Spanish of this article are available from the Editorial Office in Paris and from the Union website www.theunion.org] 
relapse, treatment after failure, treatment after default (now known as loss to follow-up), and 'other,' which consists largely of patients who have smearnegative or extra-pulmonary recurrence. The underlying disease processes, and therefore clinical outcomes, may vary significantly between these categories. For example, those with true relapse almost certainly have TB and are therefore likely to respond to retreatment, whereas those classified as 'other' may be presenting with symptoms caused by an alternative disease (e.g., cancer or bronchiectasis), for which anti-tuberculosis treatment will be ineffective. In addition, although drug resistance is more prevalent in people with recurrent TB than people presenting with a first episode of $\mathrm{TB}$, only a minority are infected with a resistant strain in most settings. Moreover, although recent WHO guidelines advocate phasing out the Category II regimen in favour of treatment based on DST results, a large number of patients with recurrent disease will not have microbiologically confirmed disease; decisions will therefore have to be made without information about resistance patterns on which to base treatment regimens.

We performed a protocol-driven systematic review of the literature ${ }^{7}$ to examine clinical outcomes on a $\mathrm{TB}$ retreatment regimen in both microbiologically confirmed and unconfirmed cases, including those registered as 'other.' We examined outcomes in different groups of patients to consider possible factors that may be associated with the poor outcomes seen in patients with recurrent TB.

\section{METHODOLOGY}

\section{Information sources and search strategy}

Medscape, Embase and Scopus databases were searched using the following search terms: 'Tuberculosis' 'retreat"', (Category II) and (Category 2). Searches were limited to manuscripts published in English after 1991 and concerning human subjects. A manual search of the journal Public Health Action was performed, as it was a relatively new journal and likely to publish relevant manuscripts. Reference lists of identified studies were examined for further relevant publications.

\section{Eligibility}

Prospective or retrospective cohort studies or clinical trials reporting outcomes in adult patients prescribed the Category II TB retreatment regimen were included. The review included studies published after 1991, as this was when the standardised retreatment regimen was introduced. Only studies published in English were included. Studies reporting on patients receiving regimens for $\mathrm{TB}$ other than the standard WHO Category II regimen, studies that did not use standard WHO definitions for reporting TB out- comes (cured, completed, failed, died, lost to followup, not evaluated ${ }^{8}$ ), and reports including only patients with MDR-TB receiving retreatment regimen were excluded.

\section{Study selection and data collection process}

After removal of duplicates, study titles, then abstracts, and finally full texts of manuscripts were reviewed. Two reviewers (DBC and JM) assessed manuscripts independently at each stage and, if discrepancies arose, consensus was reached by discussion between the two reviewers and a third reviewer (SBS).

Data were extracted and entered directly into a standardised spreadsheet and included details of the study design, setting, population characteristics, treatment regimens, reporting definitions, number of study participants and baseline smear status. Outcomes for the total study population and subgroups, including TB category, HIV status and INH susceptibility pattern, were recorded. An evaluation of the generalisability of each study was made based on inclusion criteria and data source.

\section{Summary measures and synthesis of results}

The specific endpoint of interest was the proportion of patients in whom an outcome of 'treatment success' was recorded. Treatment success was a composite of 'cured' and 'completed'. 'Cured' was defined as being smear-negative at the end of treatment having started smear-positive. 'Completed' was defined as finishing a course of treatment, but not meeting the criteria for cure. ${ }^{9}$ The proportion of patients with a successful treatment outcome was then calculated for each study. Data were analysed using STATA v12 (StataCorp, College Station, TX, USA) and $I^{2}$ estimates derived for the assessment of heterogeneity between studies.

\section{RESULTS}

A total of 1038 publications were identified after removing duplicates (Figure 1). After examination of 72 full-text articles, 39 studies were included in the final analysis (Table 1). ${ }^{10-48}$ The majority of the studies included in the review (33/39) were retrospective cohorts based on analyses of routinely collected data in local or national TB registers. The majority of the studies were conducted in Asia (predominantly India) or Africa. See Appendix Table A* for study details.

\footnotetext{
* The appendix is available in the online version of this article, at http://www.ingentaconnect.com/content/iuatld/ijtld/2018/ 00000022/00000010/art00006
} 


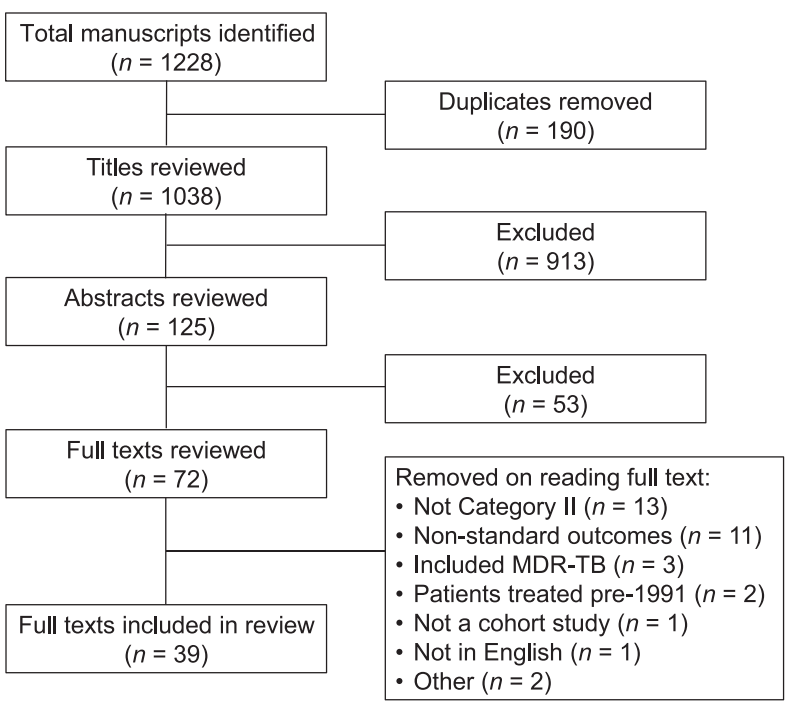

Figure 1 Study selection. MDR-TB = multidrug-resistant tuberculosis.

\section{Overall outcomes on tuberculosis retreatment regimen}

The proportion of patients successfully completing a retreatment regimen ranged from $27 \%$ to $92 \%$. There was significant heterogeneity between studies $\left(I^{2}=0.95\right)$, which precluded calculation of a pooled estimate. Only $2 / 39(5 \%)$ studies met the target of $85 \%$, successful treatment. The treatment success rate was $<75 \%$ in $29(74 \%)$ studies, and $<50 \%$ in four studies.

\section{Outcomes on tuberculosis retreatment regimen by category}

The successful completion rate in patients with $\mathrm{TB}$ relapse was $\geqslant 70 \%$ in all studies, and confidence intervals (CIs) around these estimates tended to be small (Figure 2A). Outcomes in patients registered as having returned to treatment after default or having failed treatment varied more widely, at $41-74 \%$ and $34-85 \%$, respectively (Figures $2 \mathrm{~B}$ and $2 \mathrm{C}$ ). Very few

Relapse

\begin{tabular}{|c|c|c|}
\hline Study & & $\%$ success $(95 \% \mathrm{C}$ \\
\hline Bam, 2007 & & $0.96(0.91-0.99)$ \\
\hline Chughtai, 2013 & - & $0.84(0.83-0.85)$ \\
\hline Dooley, 2011 & $\rightarrow$ & $0.74(0.68-0.79)$ \\
\hline Gninafon, 2004 & $\longrightarrow$ & $0.80(0.71-0.86)$ \\
\hline Mehra, 2008 & $\rightarrow$ & $0.76(0.72-0.80)$ \\
\hline Mukherjee, 2009 & $\rightarrow$ & $0.75(0.68-0.82)$ \\
\hline Mukhopadhyay, 2011 & $\rightarrow$ & $0.70(0.58-0.80)$ \\
\hline Munoz-Stellart, 2010 & $\rightarrow$ & $0.75(0.67-0.81)$ \\
\hline Ottomani, 2006 & • & $0.75(0.74-0.76)$ \\
\hline Pardeshi, 2007 & $\rightarrow$ & $0.73(0.65-0.80)$ \\
\hline Sarpal, 2014 & $\rightarrow$ & $0.81(0.75-0.85)$ \\
\hline Sisodia, 2006 & $\rightarrow$ & $0.83(0.78-0.87)$ \\
\hline Srinath, 2011 & + & $0.78(0.76-0.79)$ \\
\hline Takarinda, 2012 & $\longrightarrow$ & $0.80(0.71-0.86)$ \\
\hline Win, 2012 & + & $0.76(0.74-0.78)$ \\
\hline
\end{tabular}

Treatment âfter default

Study

Chughtai, 2013

Dooley, 2011

Gninafon, 2004

Mukherjee, 2009

Mukhopadhyay, 2011

Munoz-Stellart, 2010

Ottomani, 2006

Pardeshi, 2007

Sarpal, 2014

Sisodia, 2006

Srinath, 2011

Takarinda, 2012

Win, 2012

Bam, 2007
$\%$ success $(95 \% \mathrm{Cl})$

$0.71(0.69-0.72)$

$0.41(0.26-0.57)$

$0.59(0.43-0.73)$

$0.54(0.38-0.70)$

$0.57(0.39-0.73)$

$0.65(0.43-0.82)$

$0.51(0.49-0.53)$

$0.64(0.59-0.69)$

$0.67(0.55-0.76)$

$0.73(0.71-0.75)$

$0.73(0.70-0.75)$

$0.66(0.48-0.80)$

$0.74(0.69-0.78)$

(Excluded)

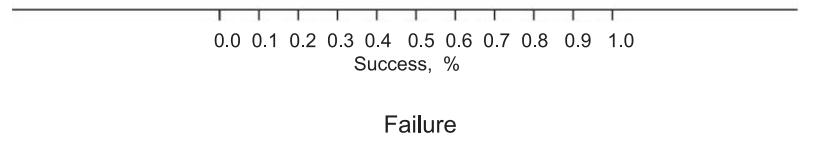

\begin{tabular}{|c|c|c|}
\hline Study & & $\%$ success $(95 \% \mathrm{Cl})$ \\
\hline Bam, 2007 & $\rightarrow$ & $0.38(0.14-0.69)$ \\
\hline Burugina Nagaraja, 2011 & $\rightarrow$ & $0.34(0.28-0.40)$ \\
\hline Chughtai, 2013 & $\rightarrow$ & $0.73(0.70-0.75)$ \\
\hline Dooley, 2011 & & $0.48(0.28-0.68)$ \\
\hline Gninafon, 2004 & & $0.85(0.75-0.91)$ \\
\hline Mehra, 2008 & $\longrightarrow$ & $0.49(0.40-0.57)$ \\
\hline Mukherjee, 2009 & 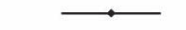 & $0.54(0.41-0.67)$ \\
\hline Mukhopadhyay, 2011 & & $0.50(0.25-0.75)$ \\
\hline Munoz-Stellart, 2010 & 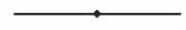 & $0.50(0.28-0.72)$ \\
\hline Ottomani, 2006 & $\rightarrow$ & $0.58(0.54-0.62)$ \\
\hline Pardeshi, 2007 & $\longrightarrow$ & $0.63(0.51-0.74)$ \\
\hline Sarpal, 2014 & 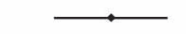 & $0.54(0.39-0.68)$ \\
\hline Sisodia, 2006 & - & $0.73(0.57-0.85)$ \\
\hline Srinath, 2011 & $\rightarrow$ & $0.59(0.55-0.64)$ \\
\hline Win, 2012 & $\rightarrow$ & $0.65(0.62-0.68)$ \\
\hline
\end{tabular}

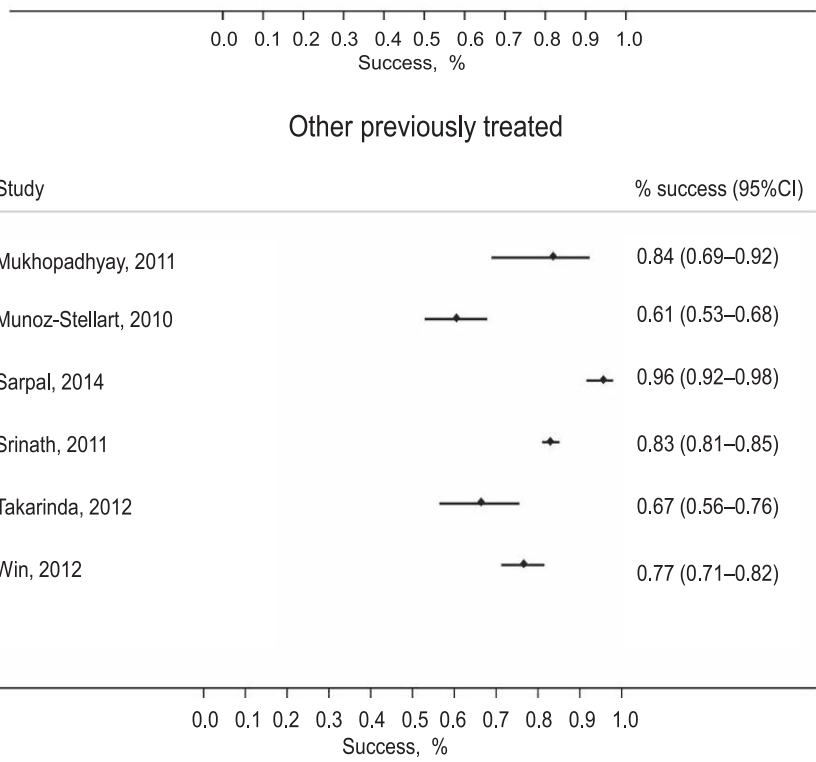

Figure 2 Treatment outcomes according to TB retreatment category: A) retreatment after relapse; B) retreatment after default (loss to follow-up); C) treatment after failure; and $\mathbf{D}$ ) other. $\mathrm{TB}=$ tuberculosis. 
Table 1 Studies describing outcomes on TB retreatment regimen

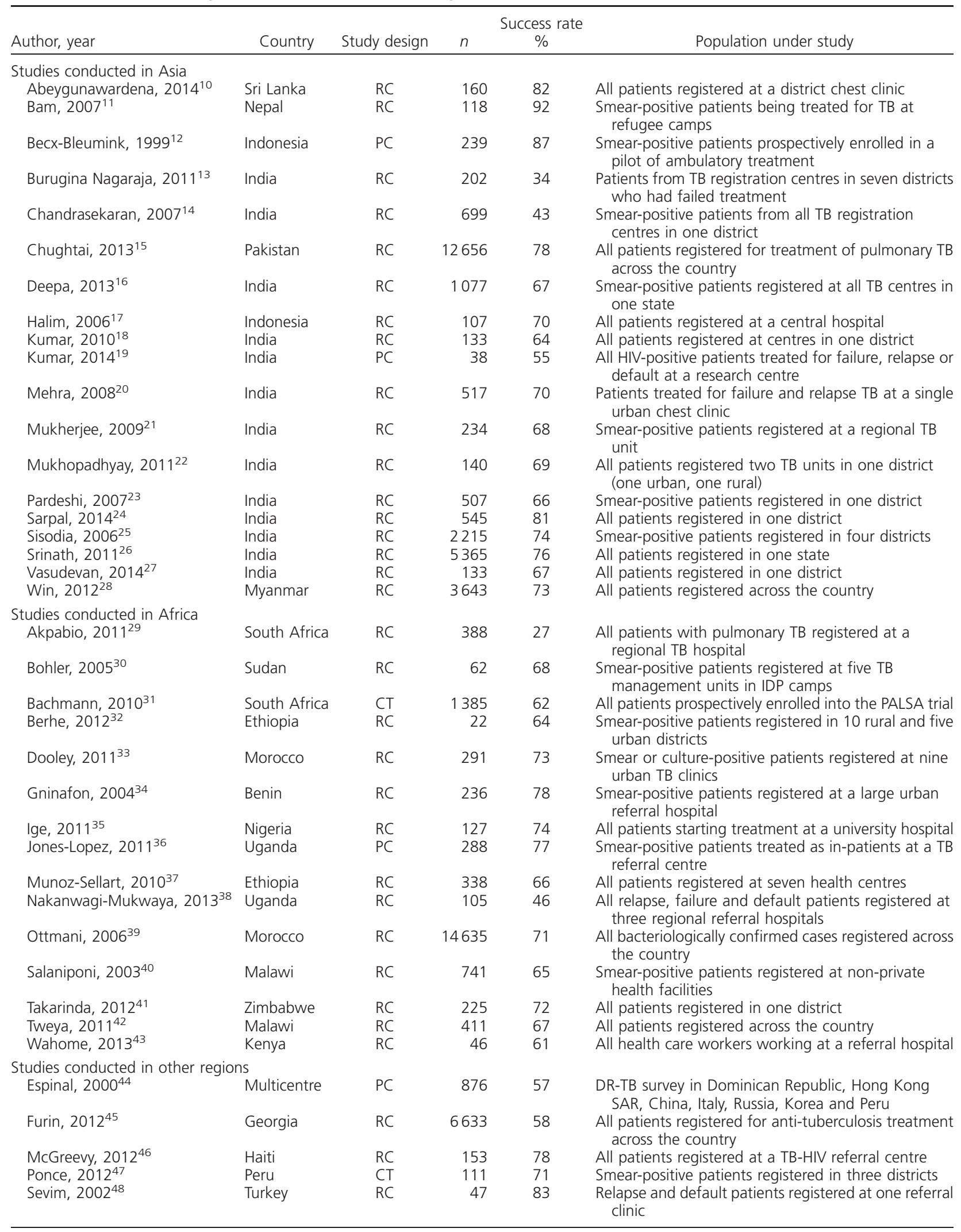

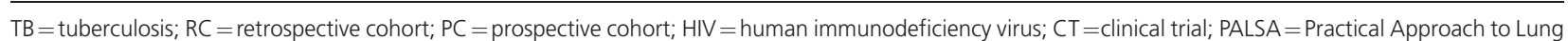
Health in sub-Saharan Africa; IDP = internally displaced persons; DR-TB $=$ drug-resistant TB; $S A R=$ special administrative region. 
Table 2 TB retreatment outcomes by INH resistance status

\begin{tabular}{lc}
\hline Study & $\begin{array}{c}\text { Treatment success in INH resistance } \\
n / N(\%)(95 \% \mathrm{Cl})\end{array}$ \\
\hline Burugina-Nagaraga, 201113 & $5 / 46(11)(4-24)$ \\
Deepa, 2013 & $80 / 144(56)(47-64)$ \\
Kumar, 2014 & $3 / 4(75)(19-99)$ \\
Salaniponi, 2003 & $18 / 23(78)(56-93)$ \\
\hline
\end{tabular}

$\mathrm{TB}=$ tuberculosis; $\mathrm{INH}=$ isoniazid

studies specifically reported outcomes in patients registered as 'other'. The rate of successful treatment in this group varied from $61 \%$ to $84 \%$ (Figure $2 \mathrm{D}$ ).

\section{Outcomes on a tuberculosis retreatment regimen by isoniazid resistance}

Disaggregated data for outcomes among patients with confirmed INH resistance were reported in four studies, involving only 217 patients (Table 2). Three of the four studies were conducted in India, and in these the prevalence of INH-R ranged from $12 \%$ to $28 \%$. The largest of the studies aimed to compare outcomes in patients with and without INH-R, and found that $44 \%$ of those with INH-R had poor treatment outcomes, compared with $31 \%$ of those infected with a susceptible strain (adjusted relative risk [aRR] 1.46, 95\% CI 1.19-1.78). ${ }^{16}$

\section{Outcomes on tuberculosis retreatment regimen by human immunodeficiency virus status}

Only five studies compared outcomes in HIV-positive and HIV-negative patients (Table 3). Two were conducted in African countries with generalised HIV epidemics (Uganda and Zimbabwe), one in Haiti (HIV prevalence $<2 \%$ ), one in Indonesia (HIV prevalence $0.5 \%$ ), and one in India (HIV prevalence $<0.5 \%$ ). In $4 / 5$ studies, outcomes were worse in $\mathrm{HIV}$-infected patients. In the one study that reported higher success rates in HIV-positive people, the number of HIV-negative patients was very small. Jonez-Lopez et al. reported an adjusted odds ratio (OR) of 2.16 (95\% CI 1.01-4.61) for unsuccessful outcome in HIV-positive patients in Uganda, with factors associated with death being CD4 count $<50$ cells/ml, no antiretroviral therapy (ART) and Karnofsky score $<70 \% .^{36}$ In a study by McGreevy et al., follow-up data demonstrated that only $46 \%$ of HIVpositive patients remained alive, in ART care and TBfree after a median of 36 months of follow-up. ${ }^{46}$

\section{DISCUSSION}

This review demonstrated that, in keeping with previous reports, rates of successful treatment using the WHO Category II regimen for TB retreatment were consistently lower than the target of $85 \%$. We presented disaggregated data available for TB retreatment subgroups; although data were limited, outcomes may have been worse in HIV-infected adults, those with INH-R, and patients with smear-negative TB and EPTB registered as 'other'.

It is often assumed that low success rates in patients on the Category II regimen are due to the increased prevalence of drug resistance in this group, which is associated with higher rates of treatment failure and relapse. ${ }^{49,50}$ With better access to molecular DST through Xpert ${ }^{\circledR}$ MTB/RIF (Cepheid, Sunnyvale, CA, USA), ${ }^{51}$ it is increasingly possible to identify patients with RMP resistance indicative of MDR-TB, who can be managed on second-line regimens. However, concerns remain regarding patients who have culture-negative TB for whom it is not possible to determine resistance patterns, and in settings where comprehensive DST is unavailable, so RMP resistance (but not INH-R) is diagnosed using Xpert. INH-R affects $12 \%$ of previously treated cases worldwide; ${ }^{52}$ however, prevalence has been estimated to vary widely between regions. ${ }^{53} \mathrm{INH}$ is a crucial component of TB treatment regimens-it has greater early bactericidal activity than other drugs and has the greatest impact on clinical outcomes. ${ }^{54,55}$ As the purpose of an extended empirical drug regimen for patients with recurrent TB is to treat presumed drug resistance, the regimen should primarily be targeted at treating INH-R. Unfortunately, few studies have reported outcomes in patients with INH-R who received the Category II regimen. Evidence for the treatment of INH-R is lacking; however, the few data available indicate that the addition of SM to the intensive phase is associated with improved outcomes. 5,56

The overall pattern of outcomes in this study suggested a lower rate of successful retreatment in patients who had failed initial anti-tuberculosis treatment than in patients who had relapsed following treatment. The high rate of treatment success in 'relapsed' patients may be largely explained by the fact that patients in this group have confirmed TB

Table 3 TB retreatment outcomes by HIV status

\begin{tabular}{|c|c|c|}
\hline Study & $\begin{array}{l}\text { Treatment success in HIV-positive patients } \\
\qquad n / N(\%)(95 \% \mathrm{Cl})\end{array}$ & $\begin{array}{l}\text { Treatment success in HIV-negative patients } \\
n / N(\%)(95 \% \mathrm{CI})\end{array}$ \\
\hline Ige, $2011^{35}$ & 27/42 (64) (49-79) & $67 / 83(81)(73-89)$ \\
\hline Jonez-Lopez, $2011^{36}$ & $103 / 140(74)(67-81)$ & $118 / 148(80)(74-86)$ \\
\hline McGreevy, 2012 46 & $41 / 56(73)(61-85)$ & 79/97 (81) (73-89) \\
\hline Srinath, $2011^{26}$ & $38 / 55$ (69) (57-81) & $97 / 111$ (87) (81-93) \\
\hline Takarinda, $2012^{41}$ & $101 / 135(75)(68-82)$ & $15 / 21(71)(52-90)$ \\
\hline
\end{tabular}

$\mathrm{TB}=$ tuberculosis; $\mathrm{HIV}=$ human immunodeficiency virus; $\mathrm{Cl}=$ confidence interval. 
disease. Furthermore, some 'relapses' may in fact be reinfections with susceptible strains. In well-run TB control programmes, failure on first-line treatment is rare and more commonly associated with drugresistant $\mathrm{TB}$ than other categories of retreatment. ${ }^{57}$ This may well account for lower success rates in this group, although drug resistance patterns were not always reported. Our findings support current treatment recommendations that, in settings where rapid DST is not routinely available, patients who have failed treatment should be started on an empirical MDR-TB regimen, unless it is known that drug resistance rates are low in that population. , $^{3,58}$

Particularly in settings where the prevalence of drug-resistant TB is low, several other factors may contribute to poor outcomes among patients with recurrent TB. First, some patients may not have TB at all, in which case the misdiagnosis will result in treating for $\mathrm{TB}$ and not the true underlying disease. While several studies have examined alternative causes of smear-negative TB in patients presenting with a first episode of TB, data exploring this issue in patients being retreated are scarce. ${ }^{59,60}$ Data from this review support such a theory, as patients classified as 'other' seemed to do worse than those who relapsed with a confirmed TB diagnosis. This is of particular concern as they make up the largest proportion of patients prescribed a retreatment regimen.

Second, other comorbid conditions which both predispose to $\mathrm{TB}$ and are associated with worse outcomes may be prevalent in this group. ${ }^{61}$ The phenomenon of post-tuberculous lung disease is well recognised. ${ }^{62-64}$ By definition, as all patients receiving the Category II regimen have had a previous episode of TB, the burden of chronic lung disease in this group is likely to be high. Those with chronic lung damage may be misclassified as having recurrent pulmonary TB or may have worse outcomes even in the event of true recurrence.

HIV-TB co-infected patients are known to have worse outcomes than HIV-negative patients after an initial episode of TB. ${ }^{65}$ Our review suggests that this is also the case in retreatment, but the underlying mechanism for this cannot be assumed to be the same. As people established on ART live for many years, but remain at an increased risk of $\mathrm{TB}$, they are more likely to have multiple TB episodes. ${ }^{66}$ An increased possibility of ART failure in patients who have been on long-term ART is likely to complicate the clinical picture of recurrent TB even further.

Third, due to prolonged treatment duration and the addition of SM to the retreatment regimen, drug toxicities may be common and result in discontinuation or interruption of treatment. ${ }^{67,68}$ Finally, this longer and more demanding regimen may be associated with poor adherence and increased rates of default from treatment.
Our study had some limitations. There remains a lack of information regarding the efficacy of the Category II regimen in different subpopulations, particularly among patients who have smear-negative or extra-pulmonary disease. Studies are also lacking from key regions such as South America and Eastern Europe. It should be noted that data evaluating the correlation between drug resistance patterns and outcomes on this regimen are insufficient.

Some obvious issues must be addressed if clinical outcomes on retreatment are to be improved. The need to identify drug resistance promptly to prevent inappropriate use of retreatment regimens is now widely recognised, and further expansion of molecular DST testing in this group is required to facilitate this strategy. However, the inability to diagnose INH$\mathrm{R}$ in most clinical settings and the lack of evidence about how to treat INH-R are key priorities to address. If randomised trials can establish the best treatment for INH-R, there may be an argument to use regimens against INH-R empirically for all patients with recurrent TB in settings where DST is not available. Lastly, it may be that compared with patients with a first TB episode, there is a higher burden of other comorbidities, such as HIV and chronic lung disease, in this population, which also needs to be addressed if outcomes are to improve.

People who receive the Category II retreatment regimen are a complex and heterogeneous group of patients. The regimen has no clinical trial evidence base and outcomes are poor across different regions and groups of patients. There are multiple possible explanations for these poor outcomes. The challenge of improving the management of recurrent TB will need to look beyond simply identifying those patients who have MDR-TB, and begin to incorporate appropriate approaches to the management of nonMDR-TB drug resistance, as well as address the spectrum of comorbidities from which patients on TB retreatment suffer.

\section{Acknowledgements}

DBC and JM received Wellcome Trust (London, UK) training fellowship grants. SBS was the supervisor for DBC and JM.

Conflicts of interest: none declared.

This is an open access article distributed under the terms of the Creative Commons Attribution License, which permits unrestricted use, distribution, and reproduction in any medium, provided the original author and source are credited.

\section{References}

1 World Health Organization. Global tuberculosis report, 2017. WHO/HTM/TB/2017.23. Geneva, Switzerland: WHO, 2017.

2 World Health Organization. Treatment of tuberculosis: guidelines. $4^{\text {th }}$ ed. WHO/HTM/TB/2009.420. Geneva, Switzerland: WHO, 2010.

3 World Health Organization. Guidelines for treatment of drugsusceptible tuberculosis and patient care. WHO/HTM/TB/ 2017.05. Geneva, Switzerland: WHO, 2017. 
4 World Health Organization. Tuberculosis control programme. 44 $4^{\text {th }}$ World Health Assembly General, 6-16 May 1991 WHA44.8. Geneva, Switzerland: WHO, 1991.

5 Menzies D, Benedetti A, Paydar A, et al. Standardized treatment of active tuberculosis in patients with previous treatment and/or with mono-resistance to isoniazid: a systematic review and meta-analysis. PLOS Med 2009; 6: e1000150.

6 Tweya H, Kanyerere H, Ben-Smith A, et al. Re-treatment tuberculosis cases categorised as 'other': are they properly managed? PLOS ONE 2011; 6: e28034.

7 Moher D, Liberati A, Tetzlaff J, Altman D G, Group P. Preferred reporting items for systematic reviews and metaanalyses: the PRISMA statement. J Clin Epidemiol 2009; 62: 1006-1012.

8 World Health Organization. Definitions and reporting framework for tuberculosis: 2013 revision. Geneva, Switzerland: WHO, 2014.

9 World Health Organization. Definitions and reporting framework for tuberculosis: 2013 revision. Geneva, Switzerland: WHO, 2013.

10 Abeygunawardena S C, Sharath B N, Van den Bergh R, Naik B, Pallewatte N, Masaima M N N. Management of previously treated tuberculosis patients in Kalutara district, Sri Lanka: how are we faring? Public Health Action 2014; 4: 105-109.

11 Bam T S, Enarson D A, Hinderaker S G, Chapman R S. High success rate of $\mathrm{TB}$ treatment among Bhutanese refugees in Nepal. Int J Tuberc Lung Dis 2007; 11: 54-58.

12 Becx-Bleumink M, Djamaluddin S, Loprang F, de Soldenhoff R, Wibowo H, Aryono M. High cure rates in smear-positive tuberculosis patients using ambulatory treatment with onceweekly supervision during the intensive phase in Sulawesi, Republic of Indonesia. Int J Tuberc Lung Dis 1999; 3: $1066-$ 1072.

13 Burugina Nagaraja S, Satyanarayana S, Chadha S S, et al. How do patients who fail first-line TB treatment but who are not placed on an MDR-TB regimen fare in South India? PLOS ONE 2011; 6: e25698.

14 Chandrasekaran V, Gopi P G, Santha T, Subramani R, Narayanan P R. Status of re-registered patients for tuberculosis treatment under DOTS programme. Indian J Tuberc 2007; 54: 12-16.

15 Chughtai A A, MacIntyre C R, Wang Y A, Gao Z, Khan W. Treatment outcomes of various types of tuberculosis in Pakistan, 2006 and 2007. East Mediterr Health J 2013; 19: 535-541.

16 Deepa D, Achanta S, Jaju J, et al. The impact of isoniazid resistance on the treatment outcomes of smear-positive retreatment tuberculosis patients in the state of Andhra Pradesh, India. PLOS ONE 2013; 8: e76189.

17 Halim H, Rasyid A, Ahmad Z. Evaluation of four-years hospital implementation of DOTS strategy (1998-2002). Acta Med Indones 2006; 38: 130-134.

18 Kumar A, Pandit V, Pattanshetty S, Shetty R, Roy S, Krish S. A study on treatment outcome of registered tuberculosis cases under RNTCP in Udupi Taluk, Karnataka. J Commun Dis 2010; 42: 45-51.

19 Kumar R, Menon P A, Ponnuraja C, et al. HIV-infected patients retreated for tuberculosis with intermittent Category II regimen-treatment outcome at 24-month follow-up. Indian J Tuberc 2014; 61: 43-50.

20 Mehra R K, Dhingra V K, Nish A, Vashist R P. Study of relapse and failure cases of CAT I retreated with CAT II under RNTCP—an eleven-year follow up. Indian J Tuberc 2008; 55: 188-191.

21 Mukherjee A, Sarkar A, Saha I, Biswas B, Bhattacharyya P S. Outcomes of different subgroups of smear-positive retreatment patients under RNTCP in rural West Bengal, India. Rural Remote Health 2009; 9: 926.
22 Mukhopadhyay S, Sarkar A P. Comparative analysis of RNTCP indicators in a rural and an urban tuberculosis unit of Burdwan district in West Bengal. Indian J Community Med 2011; 36: 146-149.

23 Pardeshi G S, Deshmukh D. A comparison of treatment outcome in re-treatment versus new smear positive cases of tuberculosis under RNTCP. Indian J Public Health 2007; 51: 237-239.

24 Sarpal S S, Goel N K, Kumar D, Janmeja A K. Treatment outcome among the retreatment tuberculosis patients under RNTCP in Chandigarh, India. J Clin Diagn Res 2014; 8: 53-56.

25 Sisodia R S, Wares D F, Sahu S, Chauhan L S, Zignol M. Source of retreatment cases under the Revised National TB Control Programme in Rajasthan, India, 2003. Int J Tuberc Lung Dis 2006; $10: 1373-1379$.

26 Srinath S, Sharath B, Santosha K, et al. Tuberculosis 'retreatment others': Profile and treatment outcomes in the state of Andhra Pradesh, India. Int J Tuberc Lung Dis 2011; 15: 105-109.

27 Vasudevan K, Jayakumar N, Gnanasekaran D. Smear conversion, Treatment outcomes and the time of default in registered tuberculosis patients on RNTCP DOTS in Puducherry, South India. J Clin Diagn Res 2014; 8: JC05-JC08.

28 Win A N, Edginton M E, Hinderaker S G, Minn N N, Linn A K. Tuberculosis treatment outcomes among retreatment patients registered by private practitioners in Myanmar. Public Health Action 2012; 2: 79-81.

29 Akpabio U S, De Villiers P J T. A description of patients with recurrence of pulmonary tuberculosis in a tuberculosis hospital, Ermelo. Afr J Prim Health Care Fam Med 2011; 3: 261.

30 Bohler M, Mustafaa S A, Morkve O. Tuberculosis treatment outcome and health services: A comparison of displaced and settled population groups in Khartoum, Sudan. Int J Tuberc Lung Dis 2005; 9: 32-36.

31 Bachmann M O, Fairall L R, Lombard C, et al. Effect on tuberculosis outcomes of educational outreach to south African clinics during two randomised trials. Int J Tuberc Lung Dis 2010; 14: 311-317.

32 Berhe G, Enquselassie F, Aseffa A. Treatment outcome of smear-positive pulmonary tuberculosis patients in Tigray Region, Northern Ethiopia. BMC Public Health 2012; 12: 537.

33 Dooley K E, Lahlou O, Ghali I, et al. Risk factors for tuberculosis treatment failure, default, or relapse and outcomes of retreatment in Morocco. BMC Public Health 2011; 11: 140.

34 Gninafon M, Tawo L, Kassa F, et al. Outcome of tuberculosis retreatment in routine conditions in Cotonou, Benin. Int J Tuberc Lung Dis 2004; 8: 1242-1247.

35 Ige O M, Akindele M O. Five year review of treatment outcome of directly observed therapy (DOT) for re-treatment pulmonary tuberculosis patients in UCH, Ibadan, Nigeria. Afr J Med Med Sci 2011; 40: 15-21.

36 Jones-Lopez E C, Ayakaka I, Levin J, et al. Effectiveness of the standard WHO recommended retreatment regimen (Category II) for tuberculosis in Kampala, Uganda: a prospective cohort study. PLOS Med 2011; 8: e1000427.

37 Munoz-Sellart M, Cuevas L E, Tumato M, Merid Y, Yassin M A. Factors associated with poor tuberculosis treatment outcome in the Southern Region of Ethiopia. Int J Tuberc Lung Dis 2010; 14: 973-979.

38 Nakanwagi-Mukwaya A, Reid A J, Fujiwara P I, et al. Characteristics and treatment outcomes of tuberculosis retreatment cases in three regional hospitals, Uganda. Public Health Action 2013; 3: 149-155.

39 Ottmani S E, Zignol M, Bencheikh N, Laâsri L, Chaouki N, Mahjour J. Results of cohort analysis by category of tuberculosis retreatment cases in Morocco from 1996 to 2003. Int J Tuberc Lung Dis 2006; 10: 1367-1372.

40 Salaniponi F M, Nyirenda T E, Kemp J R, Squire S B, GodfreyFaussett P, Harries A D. Characteristics, management and 
outcome of patients with recurrent tuberculosis under routine programme conditions in Malawi. Int J Tuberc Lung Dis 2003; 7: 948-952.

41 Takarinda K C, Harries A D, Srinath S, Mutasa-Apollo T, Sandy C, Mugurungi O. Treatment outcomes of adult patients with recurrent tuberculosis in relation to $\mathrm{HIV}$ status in Zimbabwe: a retrospective record review. BMC Public Health 2012; 12: 124.

42 Tweya H, Kanyerere H, Ben-Smith A, et al. Re-treatment tuberculosis cases categorised as 'other': are they properly managed? PLOS ONE 2011; 6: e28034.

43 Wahome E, Makori L, Gikera M, et al. Tuberculosis treatment outcomes among hospital workers at a public teaching and national referral hospital in Kenya. Public Health Action 2013; 3: 323-327.

44 Espinal M A, Kim S J, Suarez P G, et al. Standard short-course chemotherapy for drug-resistant tuberculosis: treatment outcomes in 6 countries. JAMA 2000; 283: 2537-2545.

45 Furin J, Gegia M, Mitnick C, et al. Eliminating the category II retreatment regimen from national tuberculosis programme guidelines: the Georgian experience. Bull World Health Organ 2012; 90: 63-66.

46 McGreevy J, Jean Juste M A, Severe P, et al. Outcomes of HIVinfected patients treated for recurrent tuberculosis with the standard retreatment regimen. Int J Tuberc Lung Dis 2012; 16: 841-845.

47 Ponce M, Ugarte-Gil C, Zamudio C, Krapp F, Gotuzzo E, Seas C. Additional evidence to support the phasing-out of treatment category II regimen for pulmonary tuberculosis in Peru. Trans R Soc Trop Med Hyg 2012; 106: 508-510.

48 Sevim T, Ataç G, Güngör G, et al. Treatment outcome of relapse and defaulter pulmonary tuberculosis patients. Int J Tuberc Lung Dis 2002; 6: 320-325.

49 Kritski A L, Rodrigues de Jesus L S, Andrade M K, et al. Retreatment tuberculosis cases. Factors associated with drug resistance and adverse outcomes. Chest 1997; 111: 1162-1167.

50 Lew W, Pai M, Oxlade O, Martin D, Menzies D. Initial drug resistance and tuberculosis treatment outcomes: systematic review and meta-analysis. Ann Intern Med 2008; 149: 123 134.

51 Lawn S D, Mwaba P, Bates M, et al. Advances in tuberculosis diagnostics: the Xpert MTB/RIF assay and future prospects for a point-of-care test. Lancet Infect Dis 2013; 13: 349-361.

52 World Health Organization. Anti-tuberculosis drug resistance in the world: fourth global report. WHO/HTM/TB/2008.394. Geneva, Switzerland: WHO, 2008.

53 Jenkins H E, Zignol M, Cohen T. Quantifying the burden and trends of isoniazid-resistant tuberculosis, 1994-2009. PLOS ONE 2011; 6: e22927.

54 Donald P R, Diacon A H. The early bactericidal activity of antituberculosis drugs: a literature review. Tuberculosis (Edinb) 2008; 88 (Suppl 1): S75-S83.
55 Huyen M N, Cobelens F G, Buu T N, et al. Epidemiology of isoniazid resistance mutations and their effect on tuberculosis treatment outcomes. Antimicrob Agents Chemother 2013; 57: 3620-3627.

56 Gegia M, Winters N, Benedetti A, van Soolingen D, Menzies D. Treatment of isoniazid-resistant tuberculosis with first-line drugs: a systematic review and meta-analysis. Lancet Infect Dis 2017; 17: 223-234.

57 Quy H T, Lan N T, Borgdorff M W, et al. Drug resistance among failure and relapse cases of tuberculosis: is the standard re-treatment regimen adequate? Int J Tuberc Lung Dis 2003; 7: 631-636.

58 Nahid P, Dorman S E, Alipanah N, et al. Official American Thoracic Society/Centers for Disease Control and Prevention/ Infectious Diseases Society of America clinical practice guidelines: treatment of drug-susceptible tuberculosis. Clin Infect Dis 2016; 63: e147-e195.

59 Hargreaves N J, Kadzakumanja O, Phiri S, et al. What causes smear-negative pulmonary tuberculosis in Malawi, an area of high HIV seroprevalence? Int J Tuberc Lung Dis 2001; 5: 113122.

60 Worodria W, Okot-Nwang M, Yoo S D, Aisu T. Causes of lower respiratory infection in HIV-infected Ugandan adults who are sputum AFB smear-negative. Int J Tuberc Lung Dis 2003; 7 : 117-123.

61 Metcalfe J Z, Mason P, Mungofa S, Sandy C, Hopewell P C. Empiric tuberculosis treatment in retreatment patients in high HIV/tuberculosis-burden settings. Lancet Infect Dis 2014; 14: 794-795.

62 Hicks A, Muthukumarasamy S, Maxwell D, Howlett D. Chronic inactive pulmonary tuberculosis and treatment sequelae: chest radiographic features. Int J Tuberc Lung Dis 2014; 18: 128-133.

63 Lee J J, Chong P Y, Lin C B, Hsu A H, Lee C C. High resolution chest CT in patients with pulmonary tuberculosis: characteristic findings before and after antituberculous therapy. Eur J Radiol 2008; 67: 100-104.

64 Ryu Y J, Lee J H, Chun E M, Chang J H, Shim S S. Clinical outcomes and prognostic factors in patients with tuberculous destroyed lung. Int J Tuberc Lung Dis 2011; 15: 246-250, i.

65 Aaron L, Saadoun D, Calatroni I, et al. Tuberculosis in HIVinfected patients: a comprehensive review. Clin Microbiol Infect 2004; 10: 388-398.

66 Gupta A, Wood R, Kaplan R, Bekker L G, Lawn S D. Tuberculosis incidence rates during 8 years of follow-up of an antiretroviral treatment cohort in South Africa: comparison with rates in the community. PLOS ONE 2012; 7: e34156.

67 Forget E J, Menzies D. Adverse reactions to first-line antituberculosis drugs. Expert Opin Drug Saf 2006; 5: 231249.

68 Lv X, Tang S, Xia Y, et al. Adverse reactions due to directly observed treatment strategy therapy in Chinese tuberculosis patients: a prospective study. PLOS ONE 2013; 8: e65037. 
APPENDIX

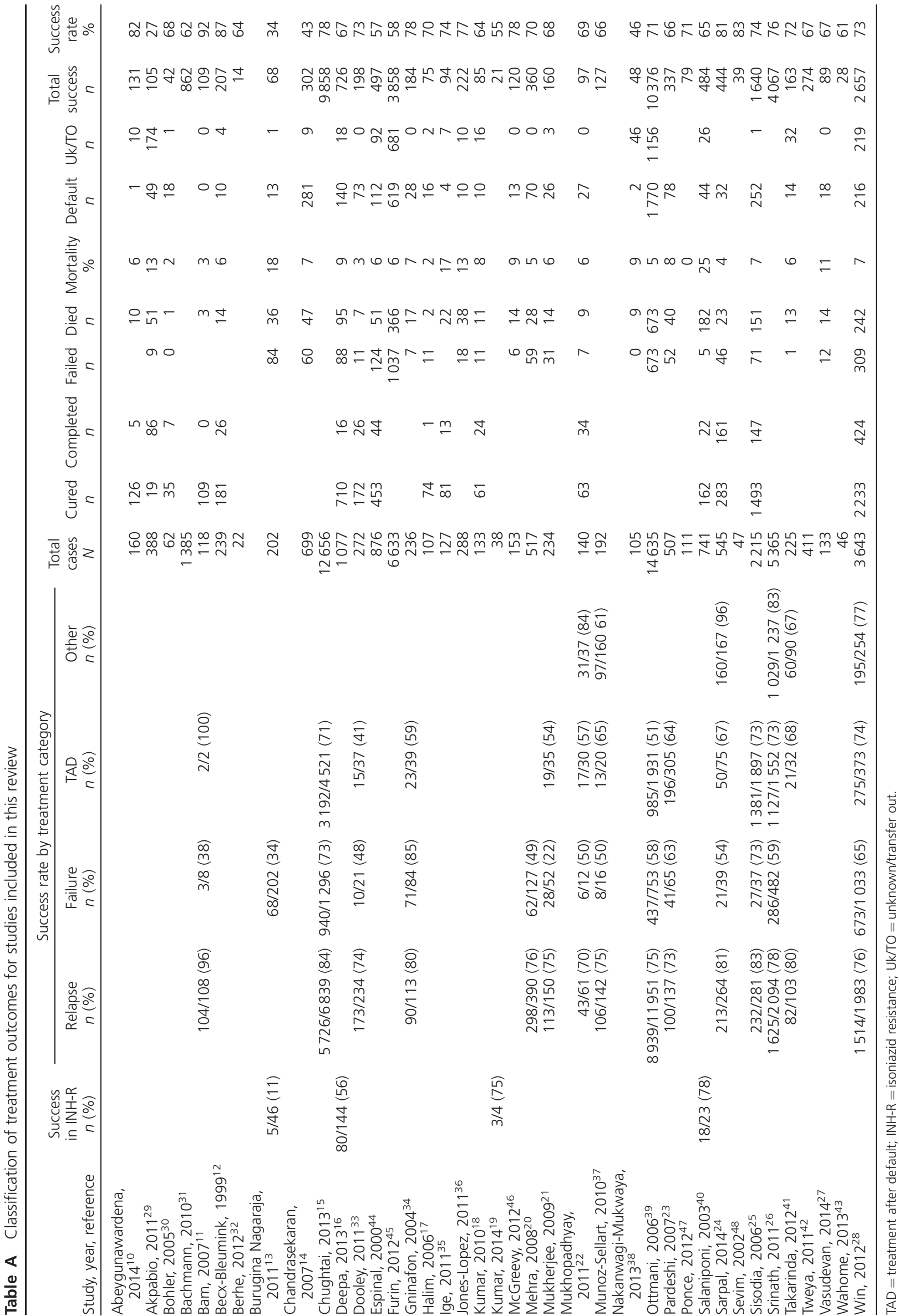


OвJECTIF : Evaluer les résultats cliniques des patients auxquels on a prescrit pour la tuberculose (TB) le protocole de retraitement de l'Organisation Mondiale de la Santé (OMS) de Catégorie II.

SCHÉ M A : Une revue systématique de la littérature a été réalisée grâce à une recherche sur les bases de données Medscape, Embase et Scopus sur les études de cohorte ou les essais cliniques rapportant les résultats de patients adultes sous protocole de retraitement de Catégorie II. RÉSULTATS : La proportion de patients qui ont achevé avec succès le protocole de retraitement a varié de $27 \%$ à $\mathbf{9 2 \%}$ dans les 39 études incluses dans la revue. Le taux de succès du traitement n'a été de $>85 \%$ que dans $2 / 39$ $(5 \%)$ études. Il y a peu de données relatives aux résultats des patients classés comme " autres " et les résultats de ce sous-groupe sont variables. Sur les cinq études rapportant des résultats désagrégés chez les personnes positives à l'infection par le virus de l'immunodéficience humaine (VIH), quatre ont démontré des résultats plus médiocres que chez les personnes VIH négatives sous protocole de retraitement. Seules quatre études ont rapporté des résultats désagrégés chez des patients ayant une résistance à l'isoniazide (INH) et le taux de succès du traitement a varié de $11 \%$ à $78 \%$.

CONCLUSION : Les résultats cliniques du protocole de retraitement de l'OMS de Catégorie II sont médiocres dans toutes sortes de populations. Les améliorations de la prise en charge devraient porter sur un traitement holistique des comorbidités et des approches intégrées de la pharmacorésistance des patients atteints de TB récurrente, incluant une approche standardisée de la prise en charge de la résistance à l'INH chez les patients qui développent une TB récurrente dans des contextes sans accès fiable à de tests exhaustifs de pharmacosensibilité.
O BJETIVO: Evaluar los desenlaces clínicos de los pacientes que han recibido un esquema de retratamiento de la tuberculosis (TB) de la Categoría II de la Organización Mundial de la Salud (OMS).

MÉ TO D O: Se llevó a cabo una revisión sistemática de las publicaciones científicas tras la búsqueda en las bases de datos Medscape, Embase y Scopus de estudios de cohortes o ensayos clínicos que comunicaban los desenlaces de pacientes adultos tratados con un esquema de retratamiento de la TB de la Categoría II.

RESULTADOS: La proporción de pacientes que completaron con éxito el esquema de retratamiento osciló entre $27 \%$ y $92 \%$ en los 39 estudios incluidos en la revisión. Solo en dos de los 39 estudios (5\%) la tasa de éxito terapéutico fue $>85 \%$. Se encontraron pocos datos sobre los desenlaces de pacientes en la categoría 'otros' y en este subgrupo los resultados fueron variables. De los cinco estudios que presentaban desenlaces desglosados en función de la infección por el virus de la inmunodeficiencia humana (VIH), cuatro revelaban desenlaces más desfavorables con el esquema de retratamiento en las personas positivas que en las personas no afectadas por el virus. Solo cuatro estudios presentaban desenlaces desglosados en los pacientes con resistencia a isoniazida (INH) y las tasas de éxito terapéutico oscilaban entre $11 \%$ y $78 \%$.

CONCLUSIÓN: Los desenlaces clínicos alcanzados con un esquema de retratamiento de la Categoría II de la OMS son deficientes en una diversidad de poblaciones. Los progresos en la gestión de los casos deben tener en cuenta el tratamiento holístico de las enfermedades concomitantes y comportar estrategias integrales frente a la farmacorresistencia en los pacientes con TB recurrente, que incluyan un esquema normalizado de tratamiento de la resistencia a INH en las personas con recurrencia de la $\mathrm{TB}$, en los entornos que no cuentan con un acceso fiable a pruebas completas de sensibilidad a los medicamentos. 